\title{
Gérard Gasarian, Le goût de l'hendiadyn dans deux poèmes de Baudelaire
}

Ida Merello

\section{(2) OpenEdition}

1 Journals

\section{Edizione digitale}

URL: http://journals.openedition.org/studifrancesi/9305

DOI: 10.4000/studifrancesi.9305

ISSN: 2421-5856

\section{Editore}

Rosenberg \& Sellier

\section{Edizione cartacea}

Data di pubblicazione: 1 juin 2008

Paginazione: 215

ISSN: 0039-2944

\section{Notizia bibliografica digitale}

Ida Merello, «Gérard Gasarian, Le goût de l'hendiadyn dans deux poèmes de Baudelaire», Studi Francesi [Online], 154 (LII | I) | 2008, online dal 10 août 2017, consultato il 08 janvier 2021. URL: http:// journals.openedition.org/studifrancesi/9305 ; DOI: https://doi.org/10.4000/studifrancesi.9305

Questo documento è stato generato automaticamente il 8 janvier 2021.

\section{(c) $(1) \&$}

Studi Francesi è distribuita con Licenza Creative Commons Attribuzione - Non commerciale - Non opere derivate 4.0 Internazionale. 


\title{
Gérard Gasarian, Le goût de l'hendiadyn dans deux poèmes de Baudelaire
}

\author{
Ida Merello
}

NOTIZIA

GÉRARD GASARIAN, Le goût de l'hendiadyn dans deux poèmes de Baudelaire, «Romantisme» $\mathrm{n}$. 131, (1-2006), pp. 115-130.

1 L'A. parte dalla constatazione che Proust, nell'ultima cronaca pubblicata su «La Nouvelle Revue française» nel giugno 1921, compie l'analisi di due poesie di Baudelaire, Chant d'automne e Causeries, interrogandosi sul motivo della brusca transizione e concludendo, dopo un minuzioso confronto stilistico e tematico, che $\mathrm{i}$ due componimenti sono assai prossimi, quasi una sorta di endiadi, figura retorica che del resto Baudelaire sembra apprezzare ampiamente a livello stilistico. 